\title{
Connecting Art Education Learning Tasks with the Artistic Field: The Factor of Quality in Art Lessons
}

Petra ŠobáŇOVÁ ${ }^{1}$ AND JANA Jiroutová ${ }^{22}$

$\approx$ This theoretical study deals with interconnecting learning tasks of art education with the parent discipline of art education (that is, with the artistic field as defined by Pierre Bourdieu, 1996), while reflecting on the quality of art lessons in the Czech Republic. The authors draw on current theoretical and empirical research of quality that identifies individual quality factors. The most salient factors are the connection with the artistic field and the resulting ability of conceptual integration, together with curricular normativity, the intentional work of the teacher with educational content, characteristics of teaching such as the support of divergence, creative approaches, associativity, imagination, reflection, searching for intersections between pupils' experience and the content of the subject, etc. The text also emphasises the fact that judgement on the quality of learning tasks should be based only on ontological-didactic and psychological-didactic aspects. The former relate to the cultural and artistic context of learning tasks, that is, the current values in the field of visual culture and the artistic field, while the latter consider the personal characteristics of each and every pupil.

Keywords: quality of art lessons, art and art education, didactics of art education, quality factors of teaching art, quality of art tasks, quality of learning tasks in art education

1 Department of Art Education, Faculty of Education, Palacký University Olomouc, Czech Republic.

$2{ }^{*}$ Corresponding Author. Department of Art Education, Faculty of Education, Palacký University Olomouc, Czech Republic; janajiroutova@seznam.cz. 


\section{Povezovanje likovnih nalog z likovnim področjem: dejavnik kakovosti pri pouku likovne vzgoje}

Petra ŠobáŇová in JANA Jiroutová

$\approx$ Teoretična študija obravnava problematiko medsebojnega povezovanja učnih nalog likovne vzgoje s celostnim pristopom (tj. $\mathrm{z}$ umetniškim področjem, kot ga je opredelil Pierre Bourdieu, 1996), hkrati pa podaja razmišljanja o kakovosti pouka likovne vzgoje na Češkem. Avtorji se opirajo na zdajšnje teoretične in empirične raziskave, ki opredeljujejo posamezne dejavnike kakovosti. Najopaznejši dejavniki so: povezava $\mathrm{z}$ likovnim področjem in posledična sposobnost konceptualne integracije skupaj s kurikularno normativnostjo, z namernim delom učitelja z izobraževalnimi vsebinami, značilnostmi poučevanja, kot so podpora divergenci, kreativni pristopi, asociativnost, domišljija, razmislek, iskanje presečišč med izkušnjami učencev in vsebino predmeta itn. V besedilu je poudarjeno tudi dejstvo, da mora presoja o kakovosti učnih nalog temeljiti le na ontološko-didaktičnih in psihodidaktičnih vidikih. Prvi se nanašajo na kulturni in likovni kontekst učnih nalog, torej trenutne vrednote na področju vizualne kulture in likovnega področja, drugi pa upoštevajo osebne značilnosti vsakega učenca.

Ključne besede: kakovost pouka likovne vzgoje, umetnost in likovna vzgoja, didaktika likovne vzgoje, dejavniki kakovosti poučevanja likovne vzgoje, kakovost likovnih nalog, kakovost učnih nalog pri likovni vzgoji 


\section{Introduction}

The key objective of this theoretical analysis is to contribute to the theoretical discourse on the role of works of art in art lessons. We will therefore discuss works of art in terms of the subject of an art task within art education. In our paper, we aim to point out that the interconnection of an art task with the artistic field contributes to the quality of the art task, and thereby also to the quality of art lessons. This thesis is based in the theory explained and clarified in the paper, and supported by two model tasks analysed in a separate section of the paper, in which we reflect on the qualitative transformation of the content of an art task that is interconnected with content from the parent discipline, that is, from the artistic field. Although the authors view the subject matter from a global perspective, reflecting on some of the key texts from abroad, the paper draws primarily on texts produced and research conducted in the Czech Republic.

The relationship between art (that is art practice and art discourse, e.g., art theory) and art education is one of the key issues of art pedagogy. At the general level, it is a problem of the relationship between the parent discipline and the subject, which all educational fields and their didactics deal with to a different extent. By parent discipline we mean a specialised field of study corresponding to the school subject (Janík \& Slavík, 2007) that fulfils the role of a reference framework from which the theory of the field of study as well as the form of its curriculum and the form of practice are derived. When addressing the issue of the parent discipline, authors Janík and Slavík (2007) use the term field of study to refer to the parent discipline in their study on the methodological problem of the relationship between the field of study and the subject. Knecht (2007) uses the term parent discipline in his review study dealing with current theoretical approaches to didactic mediation of subject matter. In our text, we also use the term reference framework, in which it is suggested that art education is closely related to the parent discipline and the content of education is compared with the content and specifics of the given parent field of study.

Art and culture are traditionally considered to be the parent discipline of art education, which is currently extended to the entire field of visual culture. A very useful term describing the parent discipline of art education is the concept of artistic field. This is the term used by French art sociologist Pierre Bourdieu (2010), who applies the term to answer the key question »What is art? «, or »What makes art? «. According to Bourdieu, the artistic field develops from the gradual historical evolution of society (it is not necessary to search for the ontology of art, but for the historical circumstances of its establishment) and the value of art is permanently produced and reproduced within that field. It is only 
the functioning of this field that creates an aesthetic disposition, without which the field - and of course art as a separate category - would not work. It is therefore the social conditions that allow the creation of an artist and their products. However, it is not just the artist who influences the course of this field; other factors, such as art historians, critics, curators and art enthusiasts, are much more involved. The artistic field is a space in which the belief in the value of art is shared and constantly renewed (ibid.) This definition seems to be suitable in the context of art pedagogy, as well, since the parent discipline of art education cannot be perceived in a limited way; for example, only as art history and a tradition codified by art production. In addition to the social context, there is a rich, sophisticated and historically changing theoretical discourse, as well as the area of art production or border areas such as design or scientific illustration and modern forms of digital visualisation. The contemporary culture of image and exposed visual communication cannot be excluded either. The concept of artistic field can include all of these areas, and they should all be considered when thinking about the curriculum or the specific content of art education.

The relationship between art education and the parent discipline has changed considerably throughout history. We could name a number of contemporary theoretical studies from the beginning of the twentieth century, which, while seeking sources of artistic expression, discovered the power of children's works and advocated their value in relation to art. The art and artistic activity of pupils were put almost on an equal footing; the intoxication of the discovery of »lost nature " prevailed and art education was attributed the ability to change the world and society. Unlike theory, however, the practice looked somewhat different. As Sokolová (2010) recalls, in relation to the educational field, art was perceived as a utility until the middle of the twentieth century: as a framework shaping tastes and a level of craft skills applicable in employment. It was the paradigmatic changes produced by interwar avant-gardes and the development of modern art that then significantly changed not only the relationship between the parent discipline and art education, but also the meaning of art education. They gradually shifted the discipline towards the so-called spontaneous-creative concept, in which the subject of the pupil is taken into account and the role of art is emphasised as a means for developing personal dispositions, cultivating creativity and expressing the pupil's subjectivity.

The concept of art - which until then was unrivalled, theorised and incomprehensible to pupils, and from which the practical aesthetic forms for teaching purposes were derived - shifted to a concept in which art becomes a testimony and self-interpretation of a person, an expression of their originality, sensitivity and uniqueness, and thus a concept to be transformed into 
educational practice. The forms of methodologies at that time contained nothing but instructions for creating ornamental compositions, and there was no attempt whatsoever to address what is today called education through art. Of course, mentioning this absence in methodologies does not mean that education through art was not being formed, as is demonstrated, for example, by $\mathrm{Li}$ chtwark's pioneering work Übungen in der Betrachtung von Kunstwerken. Nach Versuchen mit einer Schulklasse (Exercises in Contemplation of Works of Art. After Experiments with a School Class), published in Dresden as early as 1900. Children perceived as »unwritten boards with innocent eyes making art « were supposed to gain experience mainly through personal visual and emotional experiences from works and through their own artistic expression stemming from their spontaneous interest (will) to depict something (Sokolová, 2010).

This positive shift, however, had a somewhat paradoxical outcome. In the end, impulses taken from modern art often led to a considerable loosening of the links between art and teaching. The spontaneous-creative concept of art education, in which only the child's personality and their view of the world without binding norms was to be manifested through art activities, broke away from a direct and thoughtful connection with the artistic field and made do only with the creative potential of children. In some cases, art has completely disappeared from art education or has been projected only selectively (especially its generally accepted, popular, even kitschy artistic expressions). This obviously proves to be a problem, because the content of art education unrelated to the parent discipline tends to grow wild, ceasing to absorb and mediate the ongoing shifts in the parent discipline, and thus the cognitive and cultural initiation potential of the subject is lost. As Slavík summarises (2015), too much emphasis on the pupil's spontaneity weakens the view of the unique character of expressive creation and ultimately suppresses the learning functions and cognitive goals of education.

Where the curriculum framework is looser, the content is not strictly prescribed and the teacher has a considerable degree of autonomy (e.g., in the Czech Republic), this becomes an even more pressing problem. The quality of the didactic transformation of the parent discipline is fully in the hands of the educator, and often the pupils get to know only narrowly chosen concepts of art and not a relevant, representative selection. Teaching is based mainly on practical creative tasks, often without ever knowingly linking the tasks to the parent discipline or reflecting on it, as is also confirmed by research studies into practice (Šobáňová, 2016). Since postmodernism, we have not been accustomed to thinking this way: the idea of a representative selection disagrees with the diversity and richness of the artistic field, and we are not at all willing to accept 
that one selection is more relevant than another. However, it is necessary to realise that the curriculum is such a selection and reduction by its very nature.

As Dytrtová and Slavík (2019) recall, for expressive educational disciplines, including art education, it is not easy to associate theories (which play a very significant role in the case of art) with educational practice. This is not due to a lack of information resources; on the contrary, there is an overwhelming mass of knowledge in aesthetics, art theory, art history and other disciplines. However, in order for teachers to make good use of this knowledge in practice, they should selectively apply it to practical situations and creative learning tasks in the classroom. This is where the stumbling block lies, as the systematic arrangement of theoretical interpretation is usually different from the dynamic form of practical experience. In other words, the logic of the theoretician approach to educational practice cannot be derived directly from the order of theory, but first from the structure of actual experience itself (Dytrtová \& Slavík, 2019; Slavík, 2003). For this reason, our study also aims to analyse the link between art education and the parent discipline, and to point out the importance of this link as a key factor in the quality of art education.

\section{The Relationship between Art and Art Education in Contemporary Didactic Discourse}

It is clear from the initial outline that the relationship between art and art education can be viewed from many perspectives and that it is a topical and relevant problem. It is not surprising, therefore, that many experts address this topic, whether in theoretical analysis of the relationship between art and the curriculum or in discussing whether the current definition of the reference framework is still up to date and, for example, the extent to which it applies to the whole visual culture.

Certainly, the concept of this reference framework - and the different accents on one of the functions or dimensions - naturally also becomes the basis for various original concepts in art education. At random, we can mention the concept of VCAE (Visual Culture Art Education), which is characterised by an emphasis on the integration of broader visual culture into art education (supported by visual studies), as well as approaches developed in gallery education, which in turn focus on interpretation activities in the broad field of education in culture, with an emphasis on the development of pupils' cultural competence (supported by museum and gallery pedagogy and by the theory and history of art), or specific concepts such as artefiletics, a reflective conception of art education emphasising the educational dimension of art education 
and pupils' artistic creation as a first cognitive step, to be followed by the second step of reflection and dialogue between pupils as a source of new knowledge (Slavík, 1997, 2015). In this conception, art is a source of content, and education tends to both undertake cultural initiation and to understand itself through its own expression and its reflection in dialogue with others.

The relationship between the artistic field and art education is not only the topic of theoretical analyses and the core of various educational concepts, but also the subject of research. For example, Šobáňová (2016) attempted to verify, by means of a research probe, whether and how the connection with the parent discipline is actually realised in practice; in another study, she tried to identify and summarise significant shifts that have occurred in art theory, pointing out that changes in the artistic field should also be reflected in practice. Given their age and level of cognitive development, pupils should be encouraged to understand the social conditionality of art and the process of symbolisation as a key feature of all works of art; they should learn to understand that art is not necessarily beautiful and that it contains a sensory and content level through which it becomes a specific interpretation of our existence. They should also be encouraged to understand the fact that art represents reality not by mere imitation, and that the quality of a work today is not judged by the level of mimesis, but rather by the power of individual expression, the depth of world grasp, and the ability to initiate public debate (Šobáňová, 2015).

Fulková (2013) thinks along similar lines and emphasises that the particularly communicative character of visual art today, overlapping with social intervention and various novel forms of contemporary creativity, is inspiring. It highlights the role of art as a means of resistance to cultural homogenisation and creeping in societal tendencies (nationalism, patriotism, abbreviated solutions to neglected social problems), where pathology gradually becomes the norm. According to Fulková (2013), art, which is sometimes accused of having an activist character, can counterbalance the absence of critical spirit in schools, where "aestheticizing and imaginative, mind-tending and safe activities are considered a creative approach «. Art is a source of emotional, unique experiences that need to be subjected to subsequent critical reflection and a search for context (ibid.).

The issue of basing art education on working with actual art in order to ensure the quality of art lessons and art teaching is, of course, much discussed on an international level. It has been a part of global art education discourse and the topic of many research and study works for the past decades. Primarily, we would like to mention the work of Elliot W. Eisner, who dedicated most of his professional life to advocating the importance of the arts in education in 
general, and of art education in particular. In one of Eisner's (2002) key books, The Arts and the Creation of Mind, he claims that his thesis is straightforward. $\mathrm{He}$ considers the arts to be cognitive activities that are guided by human intelligence and that make unique forms of meaning possible (Eisner, 2005). However, he argues further that »the meanings secured through the arts require what might best be described as forms of artistic literacy, without which artistic meaning is impeded and the ability to use more conventional forms of expression is hampered « (Eisner, 2005, p. 76).

Kerry Freedman, another leading personality in the research of art education, deals extensively with visual literacy and the relationship between knowing and making art. In her book Teaching Visual Culture, Curriculum, Aesthetics, and the Social Life of Art, Freedman (2003) focuses on the importance of contexts of visual culture as well as on the relationships between past, present and future in postmodern visual culture. Furthermore, she places great importance on teaching visual culture in a contemporary democracy. As she goes on to explain, today "people cannot only speak freely; they can visually access, display and duplicate, computer manipulate, and globally televise. Visual culture images and objects are continuously seen and instantaneously interpreted, forming new knowledge and new images of identity and environment« (2003, p. 3). Visual culture, as Freedman maintains, mediates social relationships »between and among makers and viewers and among viewers «; she views the importance of teaching art within art education mainly in its ability to navigate learners through this image-saturated world as they represent forms of mediation »between people in which a range of professional, discursive practice plays an important role« (ibid.).

Another research study that has been carried out recently is entitled Artists and their Artworks as a Model for Improving the Quality of Teaching in Art Education and was completed by Mohammed Al-Amri (2016) and his colleagues at the Sultan Qaboos University in Oman. Making a reference to Lindsley (2006), who believed artists have a key role to play in the educational reform process and as providers of professional development, the authors' research shows that there is a strong relationship between artists and their works, on the one hand, and children's development, on the other (2016). As the authors conclude, including artworks in art lessons plays a key role in multiple areas. It proves to be beneficial not only for increasing children's motivation for learning about art, but also for developing their knowledge about multicultural art, developing their relationship with art and their ability to understand the language of art, as well as developing aesthetic sensitivity for art (ibid.).

The list goes on, but the aim of the present study is not to produce an overview of all of the works on the relationship between art and education, but 
rather to offer another perspective. We will approach this relationship from the viewpoint of the quality of art education. This is particularly important in countries where the school curriculum is traditionally looser and where teachers teach without prescribed methodological assignments. The Czech Republic is one such country. After the massive curricular reform that began in 2005, the teacher's autonomy is even greater; the teacher is actually the creator of the curriculum and follows only very loose frameworks. The educator is the one who has a fundamental influence on quality, whether through their pedagogical strategies, the specific concept and content of tasks, their concept of quality, or their preferences and relation to the parent discipline.

\section{The Relationship between Art Education and the Artistic field in the Context of the Quality of Art Lessons}

We have argued above that detaching art education from its parent discipline in practice weakens the cognitive and cultural initiation potential of the subject, and that over-emphasising pupils' spontaneity and building teaching only on practical art activities without making a link to and reflecting on the artistic field ultimately weakens the educational potential of art education, as well as its quality and relevance. In the continuation, we will analyse the relationship of art education and its parent discipline and point out the importance of this connection as an important factor in the quality of art education.

In the history of art education, it is possible to trace various time-related answers to the question of what its objective is, and what manner of education, what types of tasks or their results, can be considered as good. Quality itself naturally defies clear definition because, just like the artistic field, the practice of art education, too, is a result of changes in aesthetic values and criteria, and in our ideas about the meaning and objectives of art education.

Nevertheless, some quality factors can be found in the literature. Some reflect on various international measurements and comparisons (a comparative study on the competences of art teachers in Uhl Skřivanová, 2018; on PISA assessment see, for example, Plavčan, 2018, UNESCO: Education for All, 2000-2015, etc.), some are in the form of theoretical analysis (e.g., research by American authors associated with The Wallace Foundation, 2009; a monograph by Janík et al. entitled Kvalita (ve) vzděláváni: obsahově zaměřený přistup ke zkoumání a zlepšsování výuky [Quality (of) Education: A Content-Focused Approach to the Research and Improvement of Education], 2013; a study by Slavík and Lukavský Hodnocení kvality expresivních tvořivých úloh ve výuce (na príkladu výtvarné výchovy) [Evaluation of the Quality of Expressive Creative 
Tasks in Education (Given the Example of Art Education)] published in 2012; or a collective monograph resulting from the conference of the Czech section of INSEA and published under the title Kvalita ve výtvarné výchově [Quality in Art Education], 2019).

Among the identified quality factors can be found, for instance, curricular normativity (quality in this case means that the teaching fulfils the objectives of the curriculum); emphasising the intentional, careful and justified work of the teacher with educational content; or certain characteristics of art lessons, such as promoting divergence, a creative approach, associativity, imagination, reflection, seeking intersections between the pupil's experience and the content of the subject, etc. The quality of teaching is also directly dependent on whether learning tasks stimulate cognitive activation, the development of the semiotic function of the psyche, conceptual integration, or other higher levels of perception, thinking, feeling, expression and communication (Janík et al., 2013). Reference is made to Piaget's already classical model of mental functions and the stages of cognitive development, in which the sensomotoric, semiotic function enabling the origin and development of symbolic thinking and speech plays a key role. All of these factors do not, however, ensure quality if the group does not have a supportive learning climate created by motivated players, a climate in which experimentation is allowed and pupils can learn from their mistakes without fear of error. Reflectivity and stimulating dialogue are also mentioned as important factors of quality in art education.

The connection of art education with the parent discipline can be identified in a number of these factors. The artistic field as referred to by the authors is also a source of concrete curriculum content. In this context, Janík et al. (2013) characteristically state that the quality of teaching is based on the quality of managing this content. Of course, educational content is one of the key components of the educational process, because the teacher has to teach something, not just nothing or anything (ibid.). Thus, the path to the quality of art education takes us through the attention paid to the content of the tasks presented to the pupils, and thus to their source, to the artistic field.

In general, all educational content is related to established fields of human activity and their knowledge. It is not only knowledge in terms of information, but also in terms of the structure or system of information, the apparatus of concepts, forms and methods of cognition - in art through a work and creative process, ways of creating phenomena - concepts and artefacts.

When considering content in the context of quality, the essential fact is that content is a potentiality, a possibility that develops during education, rather than a clearly defined entity. It is something that the pupil acquires, 
understands and integrates into their structure of consciousness. Content is an option that takes place in various forms through common action and shared communication. Content manifests itself when understanding (something) and when communicating (something); only then do people realise that what they are handling has certain content (Janík et al., 2013). From this point of view, the quality of teaching is based on the realisation of this potentiality; on the other hand, poor quality teaching means wasting this possibility, not developing (in terms of education) and not acquiring (in terms of the pupil) content.

Educational content in art education is very diverse. It covers curriculumbased content, which usually includes practical expressive activities and artistic skills, and traditionally also comprises a knowledge of key artworks of the great styles: from artworks having mythological, religious and other narrative messages, to artworks whose content is fluid, less clear, just like life itself, based on a dream, birth, life, death, doubt, human fate, the problem of good and evil, otherness, disputes, harmony, and generally on the very basal ability of people to create and understand symbols and their natural tendency to transcend. (For example, the Czech curriculum sets out three general content units for art education within general education: the cultivation of sensory sensitivity, the application of subjectivity, and the verification of communication effects.)

These are types of content whose grasping (by language or non-verbal means) and sharing among people is one of the cultural foundations of our civilisation. The different ways of their didactic transformation - of the various content offered - are the results not only of differences between teachers (each of whom prefers a different type and level of content, as well as a different strategy to pass the content on), but are also based on the specificity of the content of the subject. Some methods of didactic elaboration might require science-based educational content, while others require art-related content that is usually offered in an integrated code (typically, for example, in projects and topic sets).

Janík et al. (2013) point out that the quality of teaching is further enhanced by the teacher's reflection on their own teaching, by their ongoing analysis of own practices in relation to the content, by their evaluation, design and verification of alterations, and by their attention to the quality of the tasks presented to the pupils and to the levels of the educational content transmitted. The key for each teacher is whether the tasks presented to pupils are sufficiently developed, whether their content and level of demand are adequate, and whether the tasks offer a meaningful goal.

Slavík and Lukavský (2012) refer to the multi-layered characteristics of tasks in art education, which are mostly based on artistic expression leading to an artefact as the result. The quality of the task does not, however, depend on this 
result; rather, it is determined by the overall educational impact on the pupil. In this axiom resonates the old issue of art education, which is the influence of the prevailing aesthetic norm on art education and the assessment of pupils' achievements. For now, there is a consensus that the evaluation of the quality of teaching is subject to criteria that are different from those that apply to the art activities of professionals. In education, it is necessary to ask not how good a pupil's work is, but rather what the pupil takes from the lessons, what levels of their creative, cognitive or affective abilities were encouraged during the lessons, what they managed to discover, to understand, where the task took them. Completely different criteria apply when assessing professional artistic performance.

The misunderstanding of this principle leads to epigonism, where the external signs of artworks are used without understanding their context or the context of the child's thinking and feeling. The most important thing for assessing the real quality and not only the apparent quality is to ontogenetically validate the child's attitude toward the world (Uždil, 1968). Therefore, quality assessment cannot be derived solely from the pupil's final work at art lessons. As Uždil reminds us, value is also determined by the artmaking process. A result that is unambiguous in the case of a professional artwork is not the only result in the case of a child and their artistic expression. Uždil maintains that optically compelling results can be achieved in a way that is not educationally effective at all; for example, by the pupil's carrying out every oral order of the teacher, or alone, but not on their own, moving in a closed system of visual aesthetics that the teacher has set up and the pupil elaborates on. Needless to say, this process does not develop children's creativity (Uždil, 1968).

Judgements on the quality of learning tasks must therefore consider both the ontological-didactic and psychological-didactic aspects. The first concerns the cultural context of expressivity, i.e., contemporary values in the field of aesthetics, artistic expression, expressive depiction of relationships between people, etc. (Slavík \& Lukavský, 2012), that is, the parent discipline, while the second is based on the characteristics of each pupil.

In terms of working with the content, Slavík and Lukavský (2012) consider good quality (meaning developing according to Janík et al.) learning tasks to be those that lead pupils to conceptual integration, i.e., the child's ability to give meaning to their actions, to create metaphors and symbolic expressions, to interlink contexts. This can also be perceived as the basis of artistic activities, and as such they again represent the artistic field: their application in education above all means linking education with the parent discipline. By conceptual integration, Slavík and Lukavský (2012) refer to the principle of metaphorical meaning-making based on the relevant interconnection or combination of 
concepts from different domains through an innovative interpretation. According to them, it is precisely the realisation of conceptual integration that establishes the quality of art education.

\section{Examples of Art Tasks Complementing the Thesis: Their Interconnection with the Artistic Field as a Factor of Quality}

The role of linking a task with the artistic field and the impact of this link on conceptual integration can be well demonstrated in the following tasks. They also illustrate the aforementioned importance of educational content as a factor of quality, and the potentiality of content offered in a creative activity, which can be developed to varying degrees, whereby this development (or not) creates a measure of quality.

Our model task comes from teaching practice, where it has been frequently recorded in different variations. It is based on creative work with a product of nature, specifically with stone. Its common and debatable variant is that pupils bring stones and then draw or paint on them as they choose. The result is usually a colourful artefact that often not only denies its natural origin, but is also tasteless and actually meaningless, and the task can be characterised as being of poor quality. Its disciplinary or multi-disciplinary educational potential is very low, the task can only develop basal dexterity, and the connection with the parent discipline is absent.

A variant is a classic task based on making a drawing study. Pupils draw the stone and try to capture it as faithfully as possible with respect to its overall shape, details and structure, making an effort to model space with light and shadow. This task is very popular and quite trouble-free, and drawing studies as such are inseparable from art skills training. Nevertheless, the task is weak in terms of development and therefore not of high quality. There is a link with the parent discipline, but only with its skill base: the ability of mimesis, the ability to observe and draw what we see. There is no deeper subject content, only a lower level of imaginary hierarchy of abilities (in its simple form, the task does not lead the pupil to cognitive activation or substantial development of the semiotic function of the psyche). Furthermore, the task does not take into account the psychological-didactic level and is not suitable for younger children.

If the quality of the tasks described is low and we postulate that the quality factor is the interconnection of learning tasks with the artistic field, how could they be improved? Of course, there are many possibilities, but due to limited space we will offer just two simple examples. 


\section{Figure 1-2}

A low-quality artistic task and an inspiration to improve it
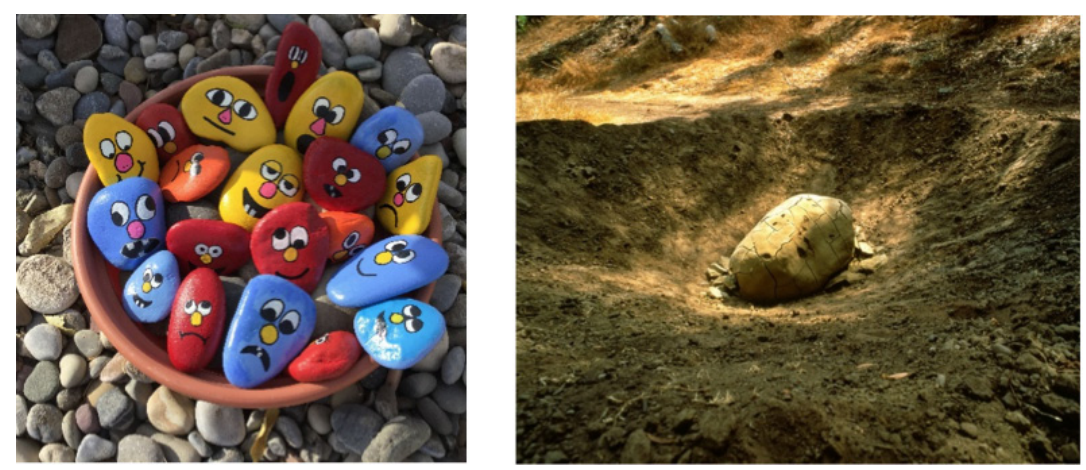

Note. Left: an example of the result of a low-quality task. Right: possible inspiration from the artistic field with the potential to improve the quality of a task. A British artist working with organic material emphasising natural processes (installation of two boulders and wooden sticks covered with clay which was monitored and documented by the artist as time took effect on the clay). From »Two Stones«, by A. Goldsworthy, 1994, photo by Philipp Scholz Rittermann.

In the case of the first task, we can make a reference to the work of British artist Andy Goldsworthy and generally to the context of land art. In light of these works, the superficiality of the original task and its insensitivity to the haptic and visual qualities of natural material, such as stone, are particularly evident. Natural materials, whether stones or flowers, leaves, pinecones or twigs, can, as in Goldsworthy's work, become an opportunity to apply a more subtle approach to nature and to cultivate sensory and ecological sensitivity. When working with natural materials, it is, of course, desirable to use their natural colours and structures. At the same time, Goldsworthy offers additional levels: he sets natural materials into unexpected contexts, regrouping them into surprising compositions without violence and with sensitivity to their nature. Presenting a task inspired by such art will show that an impressive yet sensitive and deep work can be created in a simple way and with one's bare hands. It may also make children think about the relationship between a human being and nature, the laws of nature or the nature of life and its extinction in the natural course of things. This type of work also offers the desired conceptual integration (developing the metaphor of the stone and the possible symbolic meanings of the artefacts). Another dimension offered by this task is the development of 
sensitivity towards nature, understanding our position in nature and building responsibility for the natural environment.

The point of the second task was a drawing study of a stone, and the task was to train illusive image skills, eye and hand coordination, the sensitive modelling of space, and mindfulness towards visual qualities such as shape, texture, light and shadow. How could this task be enriched and improved? This time, the original task - unlike the previous one - does not have to be eliminated completely; it can be built on. The attention of pupils can be directed to the inner structure of the stone. Specifically, using the example of minerals and the artworks entitled Květy hornin [The Flowers of Rocks] created by Czech painter and graphic artist Jiří John, which are currently part of the GASK (Gallery of the Central Bohemian Region, CZ) collections. John explored the silent processes of nature and of life in general, much like Goldsworthy, but through classical art media such as painting.

\section{Figure 3-4}

A drawing study of a stone
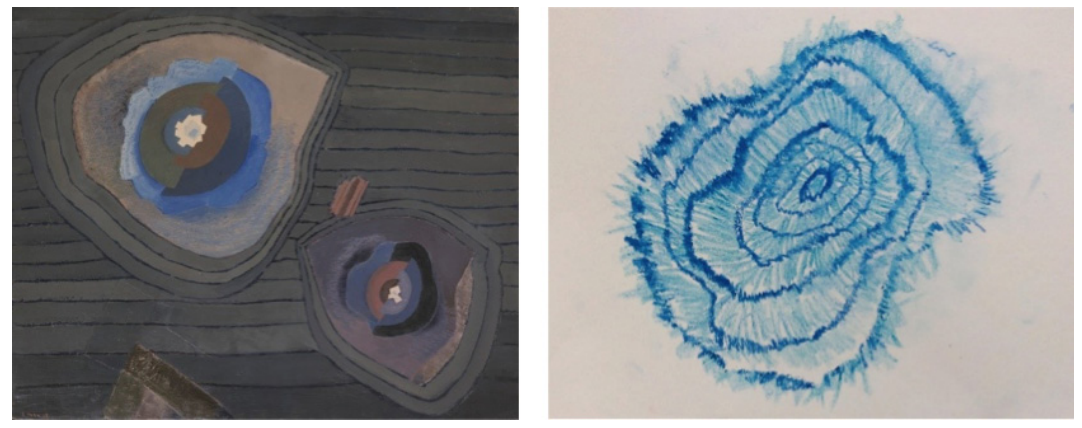

Note. Left: inspiration from the artistic field with the potential to improve the quality of a task based on the theme of stone. From J. John, Nerosty - kverty hornin [Minerals - the Flowers of Rocks], 1968, canvas, oil, GASK (Gallery of the Central Bohemian Region, CZ) collection, Kutná Hora. Right: a work by an 11-year-old boy.

The task, which we have borrowed from educator Karin Militká (to whom we are much obliged for allowing us to use the task for the purposes of this text) and which is inspired by John's work, directs pupils' attention from the surface to the inside. Pupils are encouraged to observe nature (as well as ordinary stone, we show them minerals with cut and coloured »drawings«, such as agate, malachite or amethyst) and to discover the surprising structures 
inside seemingly ordinary and not very appealing stones. We work with a moment of surprise and in the first step we encourage pupils to create their own work based on colour layering. The assignment reads as follows: Take a sheet of paper and cut or tear the largest irregular shape inspired by one of the minerals shown. You can create several. Select one of the shapes and use it as the original template. Draw the template with pastel along its edges. Then lay it on another paper and wipe the pastel from the edges of the template outwards onto the underlying paper. Gradually reduce the shape of the template by tearing or cutting. Create additional layers with pastel. Be aware that crystals in nature are formed in such a way. You can use a variety of shapes for even smaller templates. Choose the colours according to the mineral you like most. After this first step, when a drawing is created, comes a component that is just as important: reflection. In this case, it focuses on identifying the meanings of the activity and discovering the originally unexpected content. We can develop further concepts, such as the dichotomy inside $\mathrm{x}$ outside, inner $\mathrm{x}$ outer beauty, hidden, mystery, hidden treasure, etc. Working with paper and dry pastel becomes not only a means of capturing and experiencing the beauty of minerals and rocks, but also of conceptual integration; namely, the search for and reflection of layers hidden within each of us. Thus, the task develops into existential questions and its educational content is deepened considerably. Both examples show the importance of reflection, because it is only the quality of reflection on expressive activities and the interconnection of a creative process and an outcome with other contexts that determines whether an ordinary art project can gain valuable content and whether it becomes a formative impetus for the pupil. It is worth noting that a slight change to the task and the course of its implementation can make it a good-quality task, or render it entirely useless. A slight change can offer a new perspective, it can connect pupils' creativity with reflection on their subjective experience and put the artistic activity into a more general cultural context.

The description of these model tasks shows that a task based on one and the same subject matter may have different content, different levels of the same content, and quite a different quality as a whole. Many such examples would prove - as here - that educational content emanating from artistic activities and the artistic field is an open potential. Its recognition by the teacher, the appropriate way of developing it during the lesson, as well as the pupil's response to the content all determine whether one and the same stimulus or topic will become the basis of a good-quality or poor-quality task. In all cases, the source of these shifts is the connection to art. Art gives us the opportunity to seek impulses for similar, not stereotypical assignments, and also for conceptual integration and educative elevation, to which art naturally leads us through images. 
The specificity of art education is that it works with an image, in the sense of a semiotic complex of content and form. Czech philosopher Miroslav Petrríček (2009) elaborated on the philosophy of thinking in images, which offers a conceptual apparatus for grasping this particular trait. We intuitively understand this trait when looking at an eloquent image, sculpture or photographic documentation of a performance, but it is quite difficult to explain in words. Communication through image brings humankind specific knowledge of reality, which is inherent only in the image.

Of course, thinking in images is different from thinking in concepts, hence the problem of analysing expression and its outcome in language. This problem is also the reason why the content in art education often remains fallow and is not fully developed by the teacher. Sometimes this content seems obvious, immanent, but the question is whether pupils can become aware of it without being intentionally led to do so. In any case, the presence of images from the artistic field in the classroom (and not just the images of pupils) tends to be a significant impulse that makes this content more visible and reminiscent when developed in a good manner, and not superficially.

The revelation of various and sometimes surprising layers of content is at the heart of the conceptual integration mentioned above. Slavík and Lukavský (2012) also reflect on its difficulty and the fact that it requires imagination and the ability to realise the identity of the content even when changing forms. In any case, it is the conceptual integration that can become the link between the ontological-didactic and psychological-didactic levels of teaching, especially because it considers the position of the child as the unique author and recipient of the image. When reflecting on the image we can reconstruct the process of conceptual integration and learn to understand it (ibid.). As previously stated, evaluation of the quality of expressive tasks in this approach is not based solely on the evaluation of the artistic qualities of the outcome-artefact. This is understandable, because aesthetically impressive results can also occur accidentally, inadvertently, and if we appreciate them, the pupil often does not understand what quality is and how to achieve it again. On the contrary, quality depends first and foremost on the extent to which the task stimulates conceptual integration set in the context of the cultural base. The task is to inspire pupils to move metaphorically, to »jump« between different domains of meaning (ibid.). In other words, a good-quality learning task should lead the pupil to a new experience and to new knowledge by means of a creative process (ibid.).

During successful tasks that adequately accomplish conceptual integration, pupils receive more: they recognise the cultural meaning encoded during the creative process in a medium perceptible by the senses and shape the 
meanings into newly organised structures, thus creating and acquiring new content. These tasks help pupils to understand the social conditionality of art and the process of symbolisation as a key feature of all artworks (cf. Slavík \& Lukavský, 2012). Let us leave aside whether this condition can be fulfilled permanently in normal conditions, and whether art etudes or classical, craft-based art tasks or applied art in general can fit into such a concept of quality. What is essential for quality is that the connection with art and the conceptual integration inspired by it takes place to some extent, and that it motivates pupils to achieve a particular goal. The well-known Bloom taxonomy with reference to the existence of higher levels of cognitive functions to which it is desirable to lead pupils is very important here, as well. This level of content cannot be ignored, otherwise the content of the field is drastically reduced and it becomes a mere work activity. From this perspective, thinking about the possibilities of content, and ways of presenting it or offering it to pupils, as well as aiming at higher levels of content, is a prerequisite for quality, a prerequisite for achieving higher quality. This clearly is a difficult task.

\section{Conclusion}

An educational field based on practical receptive or expressive tasks has its own specific quality criteria and reference concept of a good-quality creative process and its outcome. A creative process can have value even if it is seemingly ineffective, when pupils makes mistakes, when the outcome of the task is at first glance (without contextual knowledge) of no higher value or even visibly unsuccessful; it can, of course, be an artefact, but many tasks may not have any tangible result, yet pupils learn a lot and have a valuable, formative experience.

Advocating the importance of linking teaching with the artistic field, we did not pay a great deal of attention to the possible pitfalls, so let us at least do so at the end. The practice of our field shows not only the danger that comes when teaching activities are detached from the parent discipline; there is also a second extreme: epigonism, superficial imitation of artworks by students without deeper understanding. While such tasks integrate the artistic field into education and may work well, they do not respect the psychological-didactic level. Artworks in this case are insensitive, sometimes used draconically, not as a formative stimulus and offering content to discover together, but rather as templates or colouring books. Pupils paint like van Gogh or Mondrian, but they do not know why. Such tasks cannot be of good quality, not only because they omit the psychological-didactic level, but also because they are superficial, formalistic and empty. 
Sometimes a task may seem to be of good quality because of an interesting result, but this could have occurred inadvertently and the pupil cannot understand the meaning of what they have created without reflection. However, the value in art education is not only in the resulting artefact, but also in the very process of its creation, its reflection, verification through communication, and in the establishment of personal, disciplinary and multi-disciplinary contexts. To achieve this in art education, we use the content and form of the artefact, and thinking in images. Artmaking can never be fully reflected on because grasping with words always means reduction, but resigning from verbal understanding would be a mistake that could lead to a failure to recognise and develop the content at all. In art education, the "oscillation between something and nothing « in relation to the content is ongoing, as we have seen in the variants of the stone-based tasks. The key is reflection, the effort to grasp the content in words, because, as Petríček maintains, the work itself does not say anything unless we ask it and try to establish an interview with it (Petříček, 2009). The first step, however, is recognising that the simple, unreflected "production « of an artefact (as in our painted stone) is far from exhausting the possibilities of art education.

Tasks that the teacher naturally and sensitively attaches to the parent discipline of art education, to the artistic field, i.e., tasks that have support and analogies, far exceed this basal level towards higher quality. Such teaching also naturally builds on divergence, associativity, imagination, creative approach and reflection, because art itself is such. In this sense, the teacher's task is to seek out the intersections between the pupil's experience and the content of the artistic field, and to ask developing, stimulating questions that will shape the pupil. Within this approach, the main players of quality are educators, as they select the content and didactically reduce and recontextualise it. Jaromír Uždil also emphasised the importance of the educator's erudition, their »culture « and »current artistic opinion". According to him, the teacher's unique experience and erudition cannot be replaced by any fixed and eclectic system of schooluseful rules and laws concerning colour harmony, composition, techniques, etc. (Uždil, 1968). It is the sensibility of each individual that stands above any binding rules: we, just like artists, have the tendency to violate these rules and to experimentally verify the limits of their validity and test the strength of the artistic and communication effects of their disruption. This well-known paradox of art and art education is one of the reasons why teaching in our field is difficult, but also unique and beautiful.

The paper is one of the outcomes of the project funded by the Faculty of Education, Palacký University Olomouc no. IGA_PdF_2020_031 entitled Global Narratives in Art Education and Museum and Gallery Education. 


\section{References}

Al-Amri, M., Al-Radaideh, B., Al-Yahyai, F. , Almamari, B., \& Alhajri, S. (2016). Artists and their artworks as a model for improving the quality of teaching in art education. British Journal of Arts and Social Sciences, 21(1), 59-71.

Bourdieu, P. (2010). Pravidla umění: geneze a struktura literárního pole [The rules of art: Genesis and structure of the literary field]. Host.

Dytrová, K., \& Slavík, J. (2019). »Fousatý trojúhelník « a problém analýzy úloh v expresivních vzdělávacích oborech [»A hairy triangle« and the issue of task analysis in expressive fields of study]. Kultura, umění a výchova, 7(1). http://www.kuv.upol.cz/index.php?seo_url=aktualnicislo\&casopis $=17 \&$ clanek $=196$

Eisner, W. E. (2005). Reimagining schools: The selected works of Elliot W. Eisner. Routledge.

Freedman, K. (2003). Teaching visual culture: Curriculum, aesthetics, and the social life of art.

Columbia University: Teachers College.

Fulková, M. (2013). Pedagogické a kulturologické kontexty vzdělávacích programů

Uměleckoprůmyslového musea v Praze a Galerie Rudolfinum [Pedagogical and cultural contexts of the educational programmes of the Museum of Decorative Arts in Prague and the Rudolfinum

Gallery]. In Galerijní a muzejní edukace 2: vzdělávací programy Uměleckoprůmyslového musea v Praze a Galerie Rudolfinum (pp. 13-22). Univerzita Karlova, Pedagogická fakulta.

Janík T., et al. (2013). Kvalita (ve) vzdělávání: obsahově zaměřný př́stup ke zkoumání a zlepšování výuky [Quality (in) education: A content-oriented approach to researching and improving teaching]. Masarykova univerzita.

Janík, T., \& Slavík, J. (2007). Vztah obor - vyučovací předmět jako metodologický problem [The relationship between a field of study and a subject as a methodological problem]. Orbis scholae, 2(1), 54-66.

Knecht, P. (2007). Didaktická transformace aneb od »didaktického zjednodušení« k »didaktické rekonstrukci« [Didactic transformation or from »didactic simplification« to »didactic reconstruction «]. Orbis scholae, 2(1), 67-81.

Lichtwark, A. (1900). Übungen in der Betrachtung von Kunstwerken. Nach Versuchen mit einer Schulklasse [Exercises in contemplation of works of art. After experiments with a school class]. University of California Libraries.

Lindsley, E. (2006). Teaching artist as teacher trainer. Teaching Artist Journal, 4(1), 56-62.

Petříček, M. (2009). Myšlení obrazem: průvodce současným filosofickým myšlením pro středně nepokročilé [Thinking with images: A guide to contemporary philosophical thinking for the intermediate advanced]. Herrmann \& synové.

Plavčan, P. (2018). PISA: cesta ku kvalite [PISA: The path to quality]. MSD.

Pospíšil, A., Řepa, K., \& Šobáňová, P., et al. (Eds.) (2019). Kvalita ve výtvarné výchově [Quality in art education]. Česká sekce INSEA. 
Slavík, J. (1997). Od výrazu k dialogu ve výchově. Artefiletika [From expression to dialogue in education. Artefiletics]. Karolinum.

Slavík, J., \& Lukavský, J. (2012). Hodnocení kvality expresivních tvořivých úloh ve výuce (na příkladu výtvarné výchovy) [Evaluation of the quality of expressive creative tasks in lessons (on the example of art education)]. Orbis Scholae, 6(3), 77-97.

Slavík, J. (2003). Několik poznámek k úvodníku J. Valenty »Potřebujeme didaktiku teorie?« [A few remarks on J. Valenta's editorial »Do we need didactics of theory? «]. Pedagogika, 53(2), 202-205. Slavík, J. (2015). Artefiletika - prŕležitost pro expresi v dialogu teorie a praxe [Artefiletics - An opportunity for expression in the dialogue of theory and practice]. Kultura, umění a výchova, $3(1)$. http://www.kuv.upol.cz/index.php?seo_url=aktualni-cislo\&casopis=8\&clanek=92 Sokolová, K. (2010). Výtvarná výchova - vizuálna edukácia - edukácia k umeniu [Art education visual education - education toward art]. In A. Kavčáková \& H. Myslivečková (Eds.), Josef Vydra (1884-1959) v kontextu umělecké a výtvarně pedagogické avantgardy 20. století: historie a současnost univerzitního výtvarného vzdělávání v Olomouci (pp. 183-185). Univerzita Palackého v Olomouci. Šobáňová, P. (2015). Příspěvek k teoretické analýze referenčního rámce výtvarné a galerijní pedagogiky [Contribution to the theoretical analysis of the reference framework of art and gallery pedagogy]. Kultura, umění a výchova, 3(1).

http://www.kuv.upol.cz/index.php?seo_url=aktualni-cislo\&casopis=8\&clanek=91

Šobáňová, P. (2016). Realizované vs. předepsané kurikulum - reflexe kurikulární reformy a její implementace do praxe [Implemented vs. prescribed curriculum - A reflection of curricular reform and its application in practice]. In P. Šobáňová (Ed.), Současný stav a perspektivy výtvarné výchovy: Reflexe kurikulárních dokumentů pro všeobecné vzdělávání (pp. 27-52). Česká sekce INSEA. The Wallace Foundation. (2009). Qualities of quality: Understanding excellence in arts education. https://www.wallacefoundation.org/pages/default.aspx

Uhl Skřivanová, V. (2018). Profesní kompetence učitelů v mezinárodním srovnání [Professional competence of teachers in international comparison]. Výtvarná výchova, 57(1-2), 6-19.

UNESCO. (2015). Education for all 2000-2015. UNESCO Publishing. EFA global monitoring report. Uždil, J. (1968). Umělecká kritéria ve výtvarné práci dětí [Artistic criteria in children’s art work]. In B. Maleček \& J. Brožek (Eds.), Umění a výchova: výtvarná výchova - výchova pro budoucnost: zpráva z XVIII. světového kongresu INSEA - Mezinárodní organizace pro výchovu uměním) (pp. 100-104). International Society for Education through Art. 


\section{Biographical note}

JANA JiRoutová, $\mathrm{PhD}$, is an assistant professor at the Department of Art Education where she has completed her Ph.D. studies in Art Education (Theory of Art Pedagogy and Art). In her research, she focuses on the history and development of museum and gallery education in the Anglo-American region. She gives lectures on museology, museum culture and museum and gallery education.

Petra Šobáňová, PhD, works at the Department of Art Education, Faculty of Education, Palacký University Olomouc as an associate professor in the field of didactics of art education. In addition to art pedagogy, she specialises in the field of museum and gallery pedagogy, and has earned the accreditation for the study programs of Museum and Gallery Pedagogy and Education in Culture. She participates in a number of research-based, developmental or methodological projects, either as the main researcher or as a co-researcher and external collaborator. 